\title{
Material and Relational Processes in Transitivity of A Farewell to Arms by Ernest Hemingway: A Functional Grammar Approach \\ By
}

\section{Yusra Mohammed Ramadan}

ABSTRACT

The current study aims to show how certain linguistic choices made by Hemingway help in emphasizing the themes of war in his novel $A$ Farewell to Arms by applying Halliday's System of Transitivity. Further, it tries to prove that a linguistic study of literary works may offers much more understanding of texts and contexts as well as intended meanings and ideology of an author. The linguistic analysis of the above mentioned theme in light of the Transitivity System shows that through the use of material and relational processes Hemingway highlights the effect of war on economic, social, and political conditions, offers us a live broadcast of people's life and the environment surrounding them, asserts his own negative attitude toward war and emphasizes his theme of war.

Keywords: Systemic Functional Grammar, Transitivity, A Farewell to Arms, material, relational processes, theme of war. 


\section{مستخلص - م م}

اللغويـات باعتبار هـا علم يهتم بتحليل النصـوص المكتوبـة و المنطوقـة وكل مـا يتعلق بالوسـائل

و الاختيار ات اللغوية التى يقوم بها الكاتب خلال كتابة النص فانه من خـلال التحليل اللغوي لتلك الاختيار ات

يمكن الكثف عن دو اخل واهداف الكاتب و ما يوجد خلف تلك النصوص من معان مقصودة او غير مقصودة. تهذف هذه الدر اسة الى الكثف عن الوسائل و الاختيار ات اللغويـة التى استخدمها الكاتب ارنست

هيمنجو اي و التى بدور ها اثرت موضوع الحرب فى رو ايته " وداعا للسلاح". وذلك باستخدام مبادئ نظريـة

النحو الوظيفي ، وتسعى هذه الدر اسة إلى كثف الجوانب اللفظيـة و البنيويـة و النحويـة التى تتسم بها الروايـة المختـارة ، وتحليلهـا فى إطسار نظريـة "هاليداي" للتعدد اللغوي ـ ومن خـلال التحليل اللغوى ستسعى هذه

الدر اسـة إلـى تحليـل الأسـاليب اللغويـة التـى تناولهـا هيمنجـواي و التـى تتصـف بالبسـاطة و الجمـل القصـيرة و التر اكيب المبسطة ومـا تعكسـه تلكك الاختيـار ات اللغويـة من شخصية الكاتب ، وتأثثير الخلفيـة الاجتماعيـة و السياسية خلال فترة الحرب العالمية الأولى على كتاباته كما تهدف هذه الدر اسـة لتطبيق نظريـة التعدد فى النحو الوظيفى لــ"هاليداي" على روايـة "وداعـاً للسلاح" للكاتب ارنست هيمنجواي والتي تسعى لإلقاء المزيد من الضوء على العلاقة الوثيقة بين اللغويات كعلمٍ قائٍٍ بذاته وبين المحتوى اللغوي للنصوص المكتوبة أو المنطوقة عامةً والنصوص الأدبيـة خاصـةً . كمـا أن هذه الدر اسة تسعى لكثف العلاقة بين المعنى المقصود للكاتب و التركيبات اللغويـة والنحويـة المستخدمة للتعبير عن هذه المعانى من خلال التحليل اللغوى للرواية المختارة كمادة للتحليل و الدر اسة . 


\section{Introduction}

Linguistics as a powerful tool for the interpretation of written and spoken texts is closely related to the analysis of the linguistic choices made by authors. The linguistic analysis of literary texts provides a theoretical framework within which the function and construction of the context can be described and explained. It provides a deep understanding not only of the structure, but also of the effects of the whole work that can be added to human knowledge and experience.

Transitivity is one of the various linguistic theoretical frameworks used for both literary and nonliterary text analysis. Transitivity as a functional concept adopted by Halliday (1985), refers to the way meaning is represented within a clause. The choices made in light of the system of transitivity indicate the way the writer sees the world around him. Thus a narrative would be a suitable aspect for the application as narratives construct a world using various linguistic resources. It is a microcosm of how people act, feel, think and what they value as individuals in their lives. Written texts involve the expression of ideas serving the ideational function which is concerned with the representation of the mental picture that a writer has of the world and focuses on how a writer represents experiences of who acts and who is acted upon. Since the transitivity system fulfils the ideational function, portraying the writer's world view, it could be employed as a mean of 
analysis to uncover the link between language and the way Hemingway manifests his own vision toward war in his novel A Farewell to Arms.

\subsection{Transitivity and Linguistic Analysis of Literary Texts}

Linguistics can bring about a brilliant interpretation of a textual content. It can enable us to be conscious with the experience we encounter while reading a literary text and it can help to discuss it through offering a manageable vocabulary system and an appropriate approach. It may also help in interpreting specific issues within a literary discourse by providing criteria through which we can understand why certain linguistic choices are more suitable than others. Moreover, linguistics can present new and different perspectives through which we can handle the language of a text in various ways. As stated by Halliday mentioned (1985) linguistics can be used to construct a theory about the language of a text in the form of a grammar of the text. In this sense, although linguistics does not encompass literary criticism, it is relevant to all criticism.

Literature, of all other linguistic genres, has variable and biddable linguistic features which supply many tools to be analyzed: syntactic, semantic and phonologic aspects. Brown and Yule (1983) asserted on the influence of literary analysis as means of understanding language "it is necessarily the analysis of language in use". (p. 1) 
One of the most fundamental linguistic theories that is widely adopted in literary analysis is Halliday's Systemic Functional Grammar (SFG) (1985) because it is "a theory of meaning as choice, by which a language, or any other semiotic system, is interpreted as networks of interlocking options: 'either this, or that, or the other', 'either more like the one or more like the other, and so on" ( Halliday, 1985, p. 40). According to Systemic Functional Grammar (SFG) linguistic choices made by the author are basically going around the use of language within its own

context.

\section{Methodology}

\subsection{Transitivity System: A Theoretical Background}

In systemic functional grammar meaning is equated with function. Therefore, any analysis or attempt to understand certain clauses or an intended text needs to take into consideration both meaning, form and the links between them. If a linguist tends to make an explicit and vivid explanation of a text, he/she should explain as exactly as possible how a clause has the form it does and investigate all the functions of the clause to do so. This can be attained by explaining all aspects of the way meanings are expressed. Thus, meaning is always more than a sum of individual words. There are always powerful hidden meanings beyond words.

Processes are the core of a clause from the experiential perspective. The process is typically expressed by the verbal group in the clause and also by phrasal 
verbs. The concept of process, participant, circumstance, are semantic categories which enable any event of the real world to be expressed as linguistic structures. Every major clause involves at least one participant which is realized by nominal group in the clause. In some cases, the participant may not be mentioned clearly as "you" in imperative clauses. It is understood as the "doer". Circumstances are realized by adverbial groups or prepositional phrases. It represents time, place and others.

Our most powerful impression of experience is that it consists of 'goings-on'-happening, doing, sensing, meaning and being and becoming. All these goings-on are sorted out in the grammar of the clause. Thus, as well as being a mode of action, of giving and demanding goods\& services and information, the clause is also a mode of reflection, of imposing order on the endless variation and flow of events. The grammatical system by which this is achieved is TRANSITIVITY. The transitivity system construes the world of experience into a manageable set of PROCESS TYPES.

(Halliday, 1985, p.106)

For Thompson (2004), transitivity refers to a system for describing the whole clause rather than just the verb and its object as usual. Besides, within the systemic linguistics, the notion of transitivity has been greatly extended and generalized; here the term is understood as denoting the kind of activity or process 
expressed by a clause, the number of participants involved and the manner in which they are involved.

\subsection{Processes Types}

\subsubsection{Material processes: processes of doing}

Material processes are clauses of doing physical actions and happening. They express a sequence of concrete change as it may be an entity 'does' something 'to' another one. It can be questioned "what did he/she do? And its most appropriate tense is the present in present. Material processes are subcategorized into creative and transformative. Creative processes bring Goals into existence. While transformative ones relate to some change of state of the Actor. A material clause consists of two main participants the Actor and the Goal. Halliday and Matthiessen (2004) state that "the Actor is the one that does the deed and is also the one that brings about the change" (p. 179). There must be an Actor even if it is not mentioned as in passive clauses. In this case the participant at which the process is directed is still coded as Goal because its semantic relationship has not changed, for example, The oil (Goal) is added (Process: Material) drop by drop (Circumstance). Some material clauses, not all of them, may have the above mentioned second participant, the Goal. In these material clauses, the Goal is considered an extended participant and the verb is directed at. At this point it 
should be differentiated between the transitive and intransitive material clauses in order to recognize the Goal. Throughout a material clause the Actor is the doer of the action that may in turn lead to a different outcome from the initial of the clause. This final outcome may be limited to the Actor or extended to the Goal. If the material clause represents a happening, we can call it intransitive. Alternatively, the unfolding of the process extends to another participant, the Goal. On the other hand, if the material clause represents a doing. We can call it transitive, and it is confined to the Actor (Ibid, p. 180).

Based on this, we suppose that transitivity is a system of the clause that affects not only the verb but also participants and circumstances. Consequently, if there is a Goal of a process, as well as an Actor then the representation may come in two forms: either active or passive (Ibid, p. 182).

\subsubsection{Relational processes}

As the name suggests, relational processes are being set up between two entities. This established relation may be used for describing or defining one concept for the other. So we are in confronting with Attributive or Identifying relationships. The first is Attributive relational process by which an object is ascribed to an attribute or a quality. It has two main participants the Carrier and the Attribute. The Carrier is the entity that has the mentioned feature or the 
attribute. The Attribute is the quality used for ascribing the Carrier. This second participant should be an adjective or sometimes it could be indefinite nominal group. The second one is Identifying relational process that is used to identify one concept or entity in terms of another using verb to be mainly and there may be other verbs too " there are many other examples of verbs apart from 'be' that all have an equal meaning" ( Halliday and Matthiessen, 2004, p. 238). The nature of the relation in this process can be symbolized by the equal sign '=' that these processes are reversible (if $\mathrm{x}=\mathrm{y}$, then $\mathrm{y}=\mathrm{x}$ ) (Thompson, 2014, p. 102). Once the identification here is reversible and uses real description as it is, so this means that the presented realization could be in two ways around either from general to specific or from specific to general. "The more general category is called the Value, while the specific embodiment is the Token."(Thompson, 2014, p. 103). In order to distinguish between Value and Token, we can use the verb 'represent'. If the passive form provides a better paraphrase, it is the Value that is the subject that a general value is represented by its specific Token. If the active form sounds better so It is the Token which is the subject that a specific Token represents a general Value. The direction of identification may be from general to specific or from specific to general this two ways of analysis help realizing boarder beliefs 
and ideologies of the author of the representation in other cases they suggest wider ideological beliefs and an investigation of ideological values.

In order to decide whether the under examination process is an attributive or an identifying relational process; there are some tests to help:

1- The second participant is an adjective so it is an Attributive process.

2- The second participant is a definite nominal group with (a, the, some,'s), so it is an Identifying process.

3- One or both of the participants is an embedded clause it would be an Identifying one.

4- If we can replace the verb of the process with 'represent' so it is an Identifying. 5- We can ask about the Attributive using the probe 'what is $\mathrm{X}$ like?'

6- We can ask about the Identifying using the probe 'what/which/who is X?'

7- Identifying processes can be passivized.

Although Identifying clauses are reversible, the two suggested versions may not express the same experiential meaning. So, we may have to bring two new labels which are the Identified and the Identifier which to some extend equal Value and Token but from another perspective. These two terms are much concern with the main stress of the process and with the idea on the table. The Identifier is the participant that the Identified is recognized by. The main stress of the process lies 
on the Identifier and contains or indicates the new information that is being mentioned for the first time. The Identified is the participant that already mentioned or existed before. As a result, if the main stressed idea is changed, the roles of Identified and Identifier change in turn. The usual order is Identified ${ }^{\wedge}$ Identifier because there is a general tendency in English for the main stress to fall at or near the end of an information unit to avoid complication. The two different perspectives deal with the two different labels of Value ${ }^{\wedge}$ Token and Identified ${ }^{\wedge}$ Identifier. On one hand, Value $\wedge$ Token analysis depend on the pre- existing external semantic properties of the two ways of referring to the entity whichever of the two ways is more generalized is the Value, whereas the more specific embodiment is the Token. On the other hand, Identified ${ }^{\wedge}$ Identifier depend on the unfolding language event whichever of the two ways of referring to the entity is already on the table is the Identified and the new way of referring to it is the

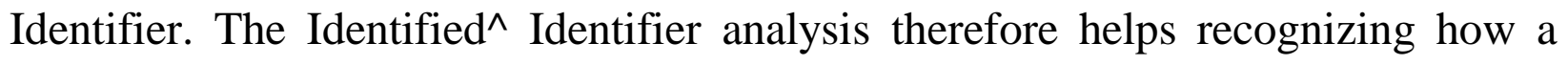
participant text is unfolding.

There are specific types of relationships expressed in the language that make difference between attributive and identifying processes. These relations are Intensive, Circumstantial and Possessive.

\subsection{2. a Intensive Attributive}


The Carrier has a quality assigned to it. The predicator need not be 'be'; it could be 'be' plus some specification. For example, the nights were cool.

\subsection{2.b Circumstantial Attributive}

It indicates time or location. We can ask about it by where/ when is $\mathrm{X}$ (the Carrier). Halliday (1985, p. 99) states that the verb of the process can be 'be' plus extra specification encoded by preposition. For example, concern= be about (Now the fighting was in the next mountain.)

\subsection{2.c Possessive Attributive}

As the name suggests they are processes of ownership. Anything is possessed can be seen as a kind of attribute. The possessed thing might be - An inhered part of a possessor (... that had a fountain and many thick shady trees).

- a temporary possessed thing (... the trees had small leaves).

- a thing possessed using verb 'belong to' (It belonged to a boy who was killed last year).

\subsection{2. d Intensive Identifying}


It identifies one entity in terms of another one. For example: This is the third day.

\subsection{2.e Circumstantial Identifying}

It has one participant expressed with a prepositional phrase and they are reversible. For example: The best place for the vase is on the table.

\section{Data Collection}

\subsection{A Farewell to Arms}

Ernest Hemingway worked as a journalist for the Kansas City Star before starting writing. He joined the Red Cross during World War I. Then he volunteered in the Spanish Civil War.

A Farewell to Arms (1929) is considered a war novel as its events were taking place during World War I in (1916). Lieutenant Frederic Henry, the protagonist and the narrator is an American who volunteered in the Italian army and worked as an ambulance driver. The opening of the novel started in winter while Henry was visiting Italy. After his return, he met the English nurse Catherine Barkley who was grieving for her fiancé's death on the front in the Somme and 
was in need for love deeply. Her passion for love affected Henry whose emotions were cool.

Henry was injured in the battle and received medication in a hospital in Milan. He needed an operation with his knee and Dr. Valantini started the surgery immediately. He was recovered under Catherine's care who moved to Milan too. During this period their relationship had been strengthened and they developed true love instead of just a rotten game or empty kisses. Henry's leg was healed, but he was diagnosed with jaundice due to extra drinking. Catherine became pregnant. Henry was sent to the front after recovery. So they had to be separated for a while.

Henry returned to the front again where shelling fires started. The Allied troops began to retreat. Henry led his group through a side road where they found two engineers and two girls. Then their car got stuck in mud but the two engineers refused to help Henry so he shot one of them. Finally they joined the retreat but the soldiers were very angry that they executed commanding officers in public. Henry escaped through diving in the river toward Milan where he rebounded with Catherine.

From Stresa to Switzerland, Henry and Catherine was trying to escape to a safe place. They settled in a town called Montreux and threw the war back. They managed at the end to live in peace. In spring, Catherine was delivering her baby 
and it was painful and hard. It was a baby boy who died at the same day followed by his mother. Henry stayed beside her till she was gone. He returned back to the hotel in rain.

\section{Data Analysis}

\subsection{Processes and themes}

\subsubsection{Theme of war}

Under theme of war come the relational process $(63 \%)$ and the material process $(56 \%)$. The novel is full of themes processed through its events by characters. Theme of war is of course the most dominated one as the novel is a war novel its events take place during World War I. The novel describes the brutal reality of war conditions. It reflects how war is a waste of life. Most of characters are against war which echoes Hemingway's own point of view. Henry and Catherine try to escape this evil by love, sex and drink. Material processes are the expressive medium by which the author handles this theme. They are related to physical actions and happenings. Hemingway tries to draw a picture how the war affect every aspect of people's life and nature too.

\subsubsection{Relational process}

Relational processes are used in order to draw a descriptive image of war for the reader. it is noted that relational processes are related to the theme of war that 
describe a vivid image of war, realities associated with it and also fantasies caused by it. The evil behind war was masterfully manifested by the use of descriptive relational processes. It helps highlighting the nasty face of war and thus justify the author's negative view of it and also the unfaithfulness of the characters. Hemingway tries to draw a picture how the war affect every aspect of people's life and nature too.

\section{Extract (1)}

...the trunks of the trees were dusty..the road was bare and white..the plain was rich with crops..the nights

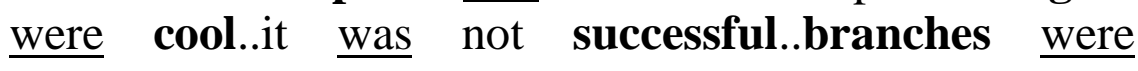
bare..the troops were muddy and wet.. beyond the plain the mountain were brown and bare in the dark. p.1 "then everything was gray" p.4

"the roads were frozen and hard as iron.. it was clear cold and dry..the snow was dry and powdery" p.9

"The men were hot and sweating." p.25

"Now in the fall, the trees were all bare and the roads were muddy.. The mulberry trees were bare and the fields were brown." p.35

"It's very hard" p.38

"my shoes were wet and warm" p.42

In extract (1) using Attributive relational process, help the reader to form a general image of attributes of everything; human, nature, abstract qualities ...etc during this critical period. Nature is described as bare, dry, gray, cool and 
hard. These adjectives are all of negative attitude as they suggest. The muddy

and wet troops reflect how are the conditions were very stubborn and inhuman.

\section{Extract (2)}

"It's a silly front" p.34

"It was a nasty place." p.36

Identifying relational processes are used to identify an entity in terms of another. Here, in extract (2) the front is identified as a silly one. The author's negative point of view towards war is very obvious and clearly declared in the first quotation. In addition, in the second quotation the front is stated as a nasty place.

\subsubsection{Material Process}

Material process is used by the author to state real and objective facts and to express these facts logically and objectively. The author aimed at describing war conditions through A Farewell to Arms. He could state those conditions clearly. Then he reflects his own opinion about the brutal war. Material processes are of “doing and happening”. War is all about doing, happening, affecting and so on. During war, soldiers and equipments are the main participants who do and be done to.

\section{Extract (1)}


Troops went by the house and down the road..the dust they raised powdered the ..leaves of the trees..and the leaves fell early that year..and the dust raising and the leaves falling..and soldiers marching..and guns were pulled by motor-tractors..and grey motors trucks that carried men..that passed in the day..the guns covered with green branches..and vines laid over the tractors..and in the fall the rain came..the leaves fell from the chestnut trees..and the trucks splashed mud on the road.p.1

Extract (1) consists of only material processes describing war. It gives us

details related to war; troops, houses, dust, soldiers, guns, trucks, tractors, muddy

roads and others. It also shows how nature reacts with war as leaves fell early in an abnormal behavior declaring giving up life that war brings nothing but death and fall.

Extract (2)

He lived in Udine..At the start of the winter came the permanent rain..with rain came the cholera..and in the end only seven thousand died. p. 2

Ironically, Hemingway states that only seven thousand died by cholera which came with rain. Here nature and war are united against man bringing death everywhere and at all levels. 


\section{Extract (3)}

The mountain was captured...and we crossed the river in August..and lived in a house in Gorizia..The river ran behind us..and the town had been captured very handsomely..but the mountains behind could not be taken..the whole thing on the Carso made the fall very different..The war was changed..The forest of oak trees..on the mountain beyond the town was gone..and the ground torn up..and the sun went a dull yellow..and the sky was covered and the cloud came on down the mountain.. The snow slanted across the wind..the bare ground was covered... p. 3

As shown in extract (3) not only people deny war but also nature refuses it. All nature elements including sun, mountains, forests and ground expressed its refusal, each in its own way: the bright sun went pale and dull, the mountains with its greatness surrendered easily, the forest of oak trees left the whole world even the ground torn up and was dressed the pale white of death.

\section{Extract (4)}

"It kills the very good and the very gentle and the very brave impartially." p.191

"I had made a separate peace." p. 187

How war is very selfish! It takes all good people, valuable things and peace without mercy. Everyone had no option but to create his own separate peace to be 
able to live in such world. This extract proves Hemingway's point of view about war and justifies his opposite attitude towards it.

\section{Conclusion and Discussion}

To conclude, there are many purposes of literature. Among them there are entertaining and gaining experiences. Further, the linguistic study of literature has many benefits. One of them is to understand any piece of literature deeply not only the door-front meaning. Thus this purpose of literature and that aim of linguistic study of literature are fulfilled promptly through the combination of Halliday's System of Transitivity and Hemingway's novel A Farewell to Arms.

The present study has provided a qualitative analysis of Ernest Hemingway's novel A Farewell to Arms adopting transitivity system of Halliday.

Throughout the analysis, it is proved that linguistic choices made in light of transitivity system orient the whole work toward perfection. It helps understanding the whole context, drawing pictures of the setting, describing characters and even manipulating emotions.

Hemingway is against war. He is a humanist whose attitude is that of viewing war as a senseless waste of life. His novel under study A Farewell to Arms is considered an anti-war novel. The main character of the novel -Henry- views war as evil and unjust. War is one of the most main dominated themes of the 
studied novel. The events of the novel take place in the front during WWI.

Hemingway's characters and linguistic choices echo his negative view towards

war. 


\section{Works Cited}

Brown, G. \& Yule, G. (1983). Discourse analysis. New York, NY: Cambridge University Press

Davidse, K. (1992). Transitivity/ Ergativity: The janus- headed grammar of actions and events. In M. Davies and L. Ravelli. London: Pinter.

Eggins, S. (1994). An introduction to systemic functional linguistics. London: Pinter.

Fawcett, R. (1973). Generating a sentence in systemic functional grammar. London: Pinter.

Fawcett, R. (1980). Cognitive linguistics and social interaction: Towards an integrated model of a systemic functional grammar and the other components of an interacting mind. Exeter\& Heidelberg: University of Exeter \& Julius Groos.

Fawcett, R. \& Halliday, M. (1987). New developments in systemic linguistics: Theory and description. London: Pinter.

Fawcett, R., Halliday, M., Lamb, S., \& Makkai, A. (1984). The semiotic of culture and language: Language and other semiotic systems of language (Vol. 2). London: Pinter.

Fowler, R. (1986). Linguistics criticism. Oxford: Oxford University Press.

Halliday, M. (1985). Language, context and text: A social semiotic perspective. Geelong: Deakin University Press. 
--- (1962). The linguistic study of literary texts. The ninth international congrss of linguistis (pp. 302-307). The Hague: Mouton.

--- (1964). Descriptive linguistics in literary studies. In A. Dithie (Ed.) Edinburgh: Edinburgh University Press.

--- (1966). Some notes on deep grammar. Journal of Linguistics, 2, 57-67.

--- (1970). Language structure and language function. In J. Lynos (Ed.) London: Penguin.

--- (1975). Learning how to mean: Explorations in the developments of language. London: Edward Arnold.

--- (1975). System and function in language. London: Oxford University Press.

--- (1977). Text as semantic choice in social contexts. In V. Dijk, and J. Petofi (Eds.) Berlin: De Gruyter.

--- (1980). Text and context: Aspects of language in a social semiotic perspective. Tokyo: Sophia University, Linguistic Institute for International Communication, Sophia Linguistica.

--- (1994). An introduction to functional grammar (2nd ed.). London: Edward Arnold.

Hasan, R. (1978). Texts in the systemic functional model. In W. Dressler (Ed.) Berlin \& New York: De Gruyter.

Huddleston, R. (1966). Systemic features and their realization. London: Pinter. 
Joia, A. \& Stenton, A. (1980). Terms in systemic linguistics: A guide to Halliday. London: Batsford.

Kress, G. (1976). Halliday: System and function in language. Oxford: Oxford University Press.

Lyne, A. (1988). Systemic syntax from a lexical point of view. In D. James, M. Cummings and W. Greaves (Eds.) Amesterdame: John Benjamins.

Mann, W. (1982). The anatomy of a systemic choice. California: University of Southern California.

Martin, J. (1983). English text: System and structure. London: Pinter.

Morley, G. (1985). An introduction to systemic grammar. London: McMillan.

Sinclair, J. (1977). Sense and Structure in Lexis. (J. Benson, M. Cummings, \& W. Greaves, Eds.) Amesterdame: John Benjamins.

Stockwell, P. ( 2008). The language and literature reader. New York, NY : Routledge.

Thompson, G. (2004). Introducing functional grammar ( $\left.2^{\text {nd }} \mathrm{ed}\right)$. London: Arnold. --- (2014). Introducing functional grammar( $\left.3^{\text {rd }} \mathrm{ed}\right)$. London: Routledge. 